\title{
Cytotoxicity properties of PM2.5 collected in Wrocław agglomeration
}

\author{
Maciej Krzysztof Bełcik ${ }^{1, *}$, and Katarzyna Piekarska ${ }^{1}$ \\ ${ }^{1}$ Faculty of Environmental Engineering, Wrocław University of Science and Technology, Wybrzeże \\ S. Wyspiańskiego 27, 50-370 Wrocław, Poland
}

\begin{abstract}
WHO report published in May 2016 presents the cities with the highest concentrations of particulate matter fraction $10 \mu \mathrm{m}$ and $2.5 \mu \mathrm{m}$ on the earth. Report presents that many of Polish cities are on the top of polluted regions in European Union. One of the cities mentioned in the report is Wrocław. Wrocław is the urban and industrial agglomeration, where air pollutions comes from three main sources: low-emissions, industrial emissions and urban traffic. In recent years, reduction in annual average concentrations of particulate matter has been observed. However Wrocław is still one of the cities in Poland, which have problems with smog situations during winter season. This article presents results of researches conducted on the particulate matter fraction $2.5 \mu \mathrm{m}$ collected in Wrocław agglomeration. Pollutions have been tested using PAN-I assay kit, which contains 4 single toxicity tests allows to check different parameters defining toxic effects on human cells. Cytotoxicity tests which are conducted are: LDH test to evaluate the integrity of cell membrane, XTT test to assess mitochondrial activity, NR test for the evaluation of the lysosomal activity and SRB test to evaluate the total protein content. Tests were performed on adenocarcinomic human alveolar basal epithelial cell line (A549), which allows to simulate conditions as close as real.
\end{abstract}

\section{Introduction}

There is more than 2,000 chemical substances in the ambient air. Some of them are in a gas form, the other are absorbed on the surface of the particulate matter. Among this ones which are absorbed on the surface of particulate matter there are inter alia polycyclic aromatic hydrocarbons, phenols, organic compounds and many more $[1,2]$.

Particulate matter with all absorbed substances can penetrate the human respiratory system may cause health problems among which it is worth mentioning asthma, pneumonia, decreased lung function and cardiovascular system. The smaller particulate matter can penetrate deeper parts of airways and reach directly into alveoli. All these factors cause health problems induced by dust pollutions are observed not only in groups exposed to environmental risk (children and elderly people) but also in health part of population $[3,4]$.

*Corresponding author: maciej.belcik@pwr.edu.pl 
Recently in May 2016 the World Health Organization present the report with the average concentrations of particulate matter fraction $10 \mu \mathrm{m}$ and $2.5 \mu \mathrm{m}$ obtained in cities among the world. The data presented by WHO comes from local air quality monitoring centres. In a report appears many of Polish cites which are on the top the polluted regions in European Union. One of the mentioned cities is Wrocław - the urban and industrial agglomeration, where air pollutions comes from three main sources: low-emissions, industrial emissions and urban traffic. Although the air quality in our city was improved in recent years and it has been observed reduction in annual average concentrations of particulate matter, there are still happened smog situations especially in winter season. The biggest problem in particulate pollution in Wrocław agglomeration is low emission caused by low quality coal combusted for heating houses not connected to the central heating network [5].

\section{Cytotoxicity}

Cytotoxicity of chemical substances is called properties that can cause disturbances in the functioning of the cells of living organisms, organs or whole organism, which could lead to their death [6].

There are described many cytotoxicity tests in the literature, but in the studies of particulate matter extracts so far mainly researches conducted by directly contact method with monolayer cell cultures were reported. The most commonly used to this type of tests were cell lines A549 obtained from human lungs and L929 obtained from rat fat tissue $[7,8]$.

With the development of environmental toxicity tests it was created new methods of assessment, which are characterized by considerably reliability, speed and simplicity in conducting and evaluating test results. One of new test is PAN-I assay, which allows to examine four different parameters of cytotoxicity using the same cell culture. Using PAN-I assay allows to evaluate the integrity of cell membrane, assess mitochondrial activity, evaluate lysosomal activity and the total protein content. All this single tests can be conducted one by one on the same cells [9].

\section{Materials and methods}

\subsection{Particulate matter collection and extraction}

Material for research was particulate matter air pollutions fraction $2.5 \mu \mathrm{m}$ collected in Wrocław agglomeration (Poland). In Wrocław lives about 630 thousand residents with average density of population 2.1 thousand people per square kilometre. Samples were collected using high-flow air aspirators on glass filters from two places located in Wrocław over all year long. This allows to gather samples from four different seasons: spring, summer, autumn and winter.

The first location (1) was area of water treatment plant at the Na Grobli Street which is located at a certain distance from busy traffic routes and houses. However, this place are located in the area of impact of low-emission. Second location (2) was within a city centre, directly at the Wiśniowa Street. In the neighbourhood of intake there are placed single- and multi-family residential buildings the majority of which are not connected to the city heating network. In the Figure 1 was marked location of samples collection on the Wrocław map. 
Before and immediately after the collection filters were weighed and differences in their weight was the mass of gathered particulate matter. Extraction of pollutants absorbed on the surface of dust was conducted in Soxhlet apparatus without absence of light and using dichloromethane as a dissolvent. After extraction the solvent were vaporized to dryness in vacuum evaporator [10].

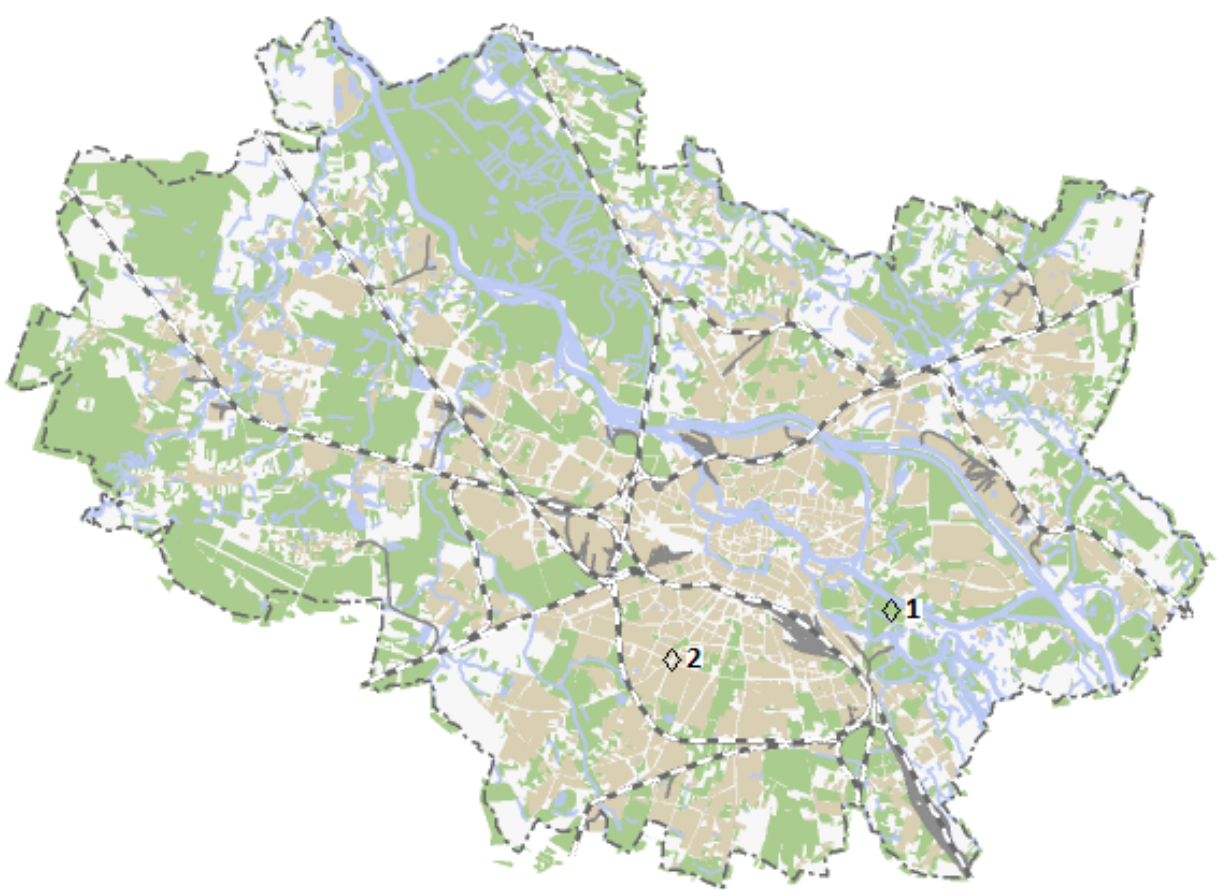

Fig. 1. Location of sample points on the Wrocław map.

\subsection{A549 cell line}

Cytotoxicity tests were performed on the A549 cell line which are adenocarcinomic human alveolar basal epithelial cells (American Type Culture Collection, Cell Culture Line 185). The choice of adherent A549 cells allows to stimulate conditions as close as in real ingress finest fractions of particulate matter pollutions to the alveoli. A549 cell line is widely used as an in vitro model for various studies, including cytotoxicity studies of air pollutions [7, 11].

Breeding of A549 cell line was carried out in culture medium Dulbeco containing 10\% addiction of calf serum, $2 \mathrm{mM}$ L-glutamine, $100 \mathrm{units} / \mathrm{cm}^{3}$ penicillin and $100 \mu \mathrm{g} / \mathrm{cm}^{3}$ streptomycin. Cell culture was incubated at $37^{\circ} \mathrm{C}$ and $5 \%$ of carbon dioxide atmosphere.

\subsection{PAN-I cytotoxicity test}

Cytotoxicity tests were performed using PAN-I assay containing four single tests to evaluate different parameters defining toxic effects on cells. Parameters measured by PAN-I assay was: integrity of cell membrane (LDH test), mitochondrial activity (XTT test), lysosomal activity (NR test) and total protein content (SRB test). All tests were performed on the same breeding of A549 cells in the 96-well plates. On the monolayer cell culture it was applied particulate matter fraction $2.5 \mu \mathrm{m}$ extracts with appropriate dilutions. The 
exposure time was 48 hours. After that it was performed all toxicity tests starting from $\mathrm{LDH}$ according to the instruction of use. As a positive controls was used solvent (DMSO) and as a negative control Triton $\mathrm{X}-100$.

Only LDH test was performed in the supernatant of the culture medium with using kinetic results reading by the time 1 hour at $22^{\circ} \mathrm{C}$ and 2 min interval. Other tests were used on the original cells washed after each one with PBS solution. Results of the PAN-I assay was reading by the spectrophotometer $\mu$ Quant with a specific wavelengths. The used wavelength was as follow: $340 \mathrm{~nm}$ for LDH test, $480 \mathrm{~nm}$ for XTT test and $540 \mathrm{~nm}$ for NR and SRB tests. In XTT, NR and SRB test it was also used reference wavelength of $690 \mathrm{~nm}$.

\section{Results}

Results of cytotoxicity tests are shown as $\mathrm{EC}_{50}$ parameter. $\mathrm{EC}_{50}$ means a concentration which causing $50 \%$ inhibition of observed effect. Table 1 presents concentration of particulate matter fraction $2.5 \mu \mathrm{m}$ causing $50 \%$ inhibition at an appropriate wavelength light absorbance. The lowest concentration presented in table means more toxic effects of particulate matter.

Table 1. $\mathrm{EC}_{50}$ concentrations of particulate matter extracts.

\begin{tabular}{|c|c|c|c|c|c|}
\hline $\begin{array}{c}\text { Location } \\
\text { point }\end{array}$ & Season & LDH & XTT & NR & SRB \\
\hline \multirow{4}{*}{$\begin{array}{c}\text { Na Grobli } \\
\text { Street }\end{array}$} & Spring & 14.000 & 6.258 & 3.938 & 3.622 \\
\cline { 2 - 6 } & Summer & 36.000 & 9.048 & 4.793 & 4.566 \\
\cline { 2 - 6 } & Autumn & $>50.000$ & 5.129 & 2.283 & 2.483 \\
\cline { 2 - 6 } & Winter & 6.000 & 3.413 & 1.541 & 1.207 \\
\hline \multirow{4}{*}{$\begin{array}{c}\text { Wiśniowa } \\
\text { Street }\end{array}$} & Spring & 23.000 & 11.682 & 5.687 & 4.674 \\
\cline { 2 - 6 } & Summer & $>50.000$ & 30.757 & 18.773 & 15.570 \\
\cline { 2 - 6 } & Autumn & 26.000 & 5.120 & 2.769 & 2.810 \\
\cline { 2 - 6 } & Winter & 43.000 & 17.300 & 6.045 & 5.634 \\
\hline
\end{tabular}

\section{Discussion}

Comparing the $\mathrm{EC}_{50}$ results obtained in different cytotoxicity tests it is clearly shown higher values in case of LDH test then in other ones. The fact of much higher result values in LDH assay is connected with method of results reading. Disorders in spectrophotometry results is related with colour of the particulate matter extract sample. A LDH test is only one which reading is conducted in supernatant. This fact is the reason that the colour of the samples can disturb results of spectrophotometer reading at wavelength $340 \mathrm{~nm}$. Described problem is not presented in publications conducted by other authors on A549 cell line, but the testing procedure in this cases is different from PAN-I instruction [12-14].

Values of $\mathrm{EC}_{50}$ concentrations obtained in other three tests are more objective and similar to each other. It should be also noted, that the results in XTT assay are slightly higher than those obtained in NR and SRB test. Presented results confirmed cytotoxicity properties of particulate matter fraction $2.5 \mu \mathrm{m}$ in relation to the adenocarcinomic human 
alveolar basal epithelial cells A549. Impact of the particulate matter and organic extracts were also investigated by other authors. Among many results of researches it was measured apoptosis an viability of cells and cytotoxic effects using different parameters tests $[11,14-16]$.

Obtained results shows differences in toxicity of samples collected in different seasons of the year. Particulate matter collected on $\mathrm{Na}$ Grobli Street during autumn and winter season shows cytotoxicity properties in lower concentration then collected in spring and summer season. Similar situations shows results obtained on Wiśniowa Street, but in this case spring and winter concentrations are close to each other. This situation is connected with the more intensity of low-emission of particle pollutions connected to the combustion of the poor quality coal and waste burning.

Presented results shows also differences in toxicity depending on consumption place. Lower cytotoxicity properties showed samples collected near Wiśniowa Street, than near Grobla Street. This may be due to collection point near Wiśniowa gather particulate point coming typically from local sources of formation. The overwhelming amount of dust in this point is traffic pollutions and particulate matter coming from the combustion of nearly objects. Collecting point located near Na Grobli Street, which is at some distance from the sources of contamination, gather mixture of particulate matter comes from sources all over the city. This differences types of substances absorbed on the particulate matter fraction $2.5 \mu \mathrm{m}$ can create complicated mixtures with unknown properties and functions.

\section{Conclusions}

The presented test results allow to present following conclusions:

1. It has been observed differentiation between an obtained results depending on the place and the season of collection.

2. It was proved higher cytotoxicity properties of particulate matter fraction $2.5 \mu \mathrm{m}$ collected during autumn-winter season than in spring-summer season.

3. It was found that particulate matter collected on the Wiśniowa Street showed higher values of $\mathrm{EC}_{50}$ than samples collected on $\mathrm{Na}$ Grobli Street.

4. It has been shown inaccuracy of LDH test in conducted formula. It is proposed to change the method of carrying out, to not read the results in supernatant.

5. It has been shown similarity the results of $\mathrm{EC}_{50}$ obtained in the NR test and SRB test.

6. It has been observed lower sensitivity of the XTT test with respect to the NR test and SRB test.

7. It has been confirmed effectiveness of using A549 cell line in researches of particulate matter fraction $2.5 \mu \mathrm{m}$.

The investigations were co-financed within the framework of the order No. 0401/0068/16 with the specific subsidy granted for the Faculty of Environmental Engineering Wroclaw University of Science and Technology (W-7) by the Minister of Science and Higher Education.

\section{References}

1. D.K.M Alves, F. Kummrow, A.A. Cardoso, D.A. Morales, G.A. Umbuzeiro, Environ. Mol. Mutagen., 57, 41 (2015)

2. L.D. Claxton, P.P. Matthews, S.H. Warren, Mutat. Res, 567, 347 (2004)

3. J. Burns, H. Boogaard, R. Turley, L.M. Pfadenhauer, /a./m. van Erp, A.C. Rohwer, E. Rehfuess, Cochrane Database of Systematic Reviews, Interventions to reduce particulate matter air pollution and their effect on health, Cochrane Library (2014) 
4. S.S. Lim et al., Lancet, 380, 2224 (2014)

5. Global Urban Ambient Air Pollution, WHO Report, May 2016.

6. R. Walker, Toxicologia prospective y seguridad quimica, 147 (1992)

7. K. Piekarska, M. Zaciera, A. Czarny, E. Zaczyńska, Environ. Prot. Eng., 35, 37 (2009)

8. K. Piekarska, M. Zaciera, A. Czarny, E. Zaczyńska, Environ. Prot. Eng, 37, 85 (2011)

9. M. Kamber, European Environmental Mutagen Society September 9th - 13th, 2007 Pharmazentrum University Basel, Comparison of 4 cytotoxicity assays performed sequentially on the same cell sample, Basel, Switzerland (2007)

10. B. Binková, M. Černá, A. Pastorková, R. Jelínek, I. Beneš, J. Novák, R.J. Šrám, Mutat. Res.-Fund. Mol. M., 525, 43 (2003)

11. M.E. Salcido-Neyoy, Y. Sánchez-Pérez, A.R. Osornio-Vargas, M.E. Gonsebatt, J. Meléndez-Zajgla, R. Morales-Bárcenas, P. Petrosyan, E.D. Molina-Servin, E. Vega, N. Anzano-León, C.M. Garcia-Cuellar, Environ. Pollut., 203, 175 (2015)

12. H. Líbalowá, S. Krčková, K. Uhlířová, A. Milcová, J. Schmuczerová, M. Ciganek, J. Kléma, M. Machala, R.J. Šrám, J. Topianka, Toxicology letters, 225, 350 (2014)

13. D. Breznan, S. Karthikeyan, M. Phaneuf, P. Kumarathasan, S. Cakmak, M.S. Denison, J.R. Brook, R. Vincent, Particle and Fibre Toxicology, 13, 41 (2016)

14. M. Dergham, C. Lepers, A. Verdin, F. Cazier, S. Billet, D. Courcot, P. Shirali, G. Garçon, Environ. Res., 137, 256 (2015)

15. U.S. Akhtar, N. Rastogi, R.D. McWhinney, B. Urch, C.W. Chow, G.J. Evans, J.A. Scott, Toxicology Reports, 1, 145, (2014)

16. G. Mazzarella, A. Lucariello, A. Bianco, C. Calabrese, T. Thanassoulas, L. Savarese, A. Fiumarella, V. Esposito, A. de Luca, In Vivo, 28, 557 (2014) 